Research Article

\title{
Produksi Enzim Fibrinolitik Tempe oleh Rhizopus oryzae FNCC 6078
}

\section{Production of fibrinolytic enzyme Tempeh by Rhizopus oryzae FNCC 6078}

\author{
Alicia Sada ${ }^{1}$ Noor Erma Sugijanto' ${ }^{1}$ Achmad Toto Poernomo* \\ ${ }^{1}$ Department of Pharmaceutical Chemistry, Faculty of Pharmacy, Universitas Airlangga, Surabaya, East Java, Indonesia \\ *Corresponding author E-mail: achmad-t-p@ff.unair.ac.id \\ Article History \\ Received: 28 December 2020; Received in Revision: 18 January 2021; Accepted: 8 February 2021
}

\begin{abstract}
Background Rhizopus oryzae FNCC 6078 had been evaluated producing fibrinolytic enzyme under solid state fermentation. Soybean had been used to produce fibrinolytic enzyme through fermentation in tempeh. The main purpose of this study was to reveal optimum condition for fermentation. The parameters of the condition were inoculum volume, incubation period and temperature. Optimum condition was defined by maximum fibrinolytic activity. Methode Fibrinolytic activity was measured using spectrophotometry at $274 \mathrm{~nm}$. Result optimum condition for producing fibrinolytic enzyme was $1,5 \mathrm{~mL}$ volume of inoculum of Rhizopus oryzae suspension in $25 \% \mathrm{~T}, 42$ hours for incubation period and $35^{\circ} \mathrm{C}$ temperature incubation.
\end{abstract}

Keyword : Rhizopus oryzae, tempeh, fibrinolytic enzyme, fermentation condition

\begin{abstract}
ABSTRAK
Latar Belakang Rhizopus oryzae FNCC 6078 telah dievaluasi menghasilkan enzim fibrinolitik menggunakan fermentasi solid state. Kedelai telah digunakan untuk menghasilkan enzim fibrinolitik melalui fermentasi pada tempe. Tujuan utama dari penelitian ini adalah untuk mengungkapkan kondisi optimum untuk fermentasi. Parameter kondisi adalah volume inokulum, masa inkubasi dan suhu. Kondisi optimal ditentukan oleh aktivitas fibrinolitik maksimum. Aktivitas fibrinolitik diukur menggunakan spektrofotometer pada $274 \mathrm{~nm}$. Hasil untuk setiap kondisi optimum untuk menghasilkan enzim fibrinolitik adalah volume inokulum $1,5 \mathrm{~mL}$ suspensi Rhizopus oryzae dalam $25 \% \mathrm{~T}, 42$ jam untuk masa inkubasi dan $35^{\circ} \mathrm{C}$ untuk suhu inkubasi.
\end{abstract}

Kata kunci : Rhizopus oryzae, tempe, enzim fibrinolytic, kondisi fermentasi

\section{Pendahuluan}

Di Indonesia, trombosis dapat berupa penyakit jantung koroner atau stroke yang merupakan penyebab kematian nomor satu, lebih sering dari penyakit infeksi (Bakta, 2007). Trombus merupakan bekuan darah yang komponen utamanya adalah fibrin. Sampai saat ini plasminogen aktivator dan urokinase masih banyak digunakan dalam terapi trombolisis, meskipun memiliki harga yang mahal dan efek samping yang tidak diinginkan, seperti perdarahan internal dalam saluran usus saat diberikan secara oral (Kotb, 2012).

Enzim fibrinolitik merupakan golongan protease dapat mendegradasi bekuan fibrin. Obat-obatan yang mengandung enzim fibrinolitik paling efektif untuk pengobatan trombus (Arunachalam et al., 2011). Enzim fibrinolitik dapat dihasilkan dari berbagai sumber, antara lain hewan, tumbuhan, bakteri dan jamur (Kotb, 2012). Beberapa protease telah ditemukan dalam makanan fermentasi dan berfungsi untuk mendegradasi trombus. Salah satunya adalah Natto, makanan fermentasi dari kedelai asal Jepang, yang difermentasi oleh bakteri Bacillus natto. Nattokinase adalah protease yang terkandung dalam Natto yang mempunyai aktivitas trombolitik (Sugimoto et al., 2007). Terdapat juga produk makanan yang difermentasi oleh Bacillus lain yang menghasilkan enzim fibrinolitik yang berasal dari Korea yaitu, Chungkook-jang, Doen-jang, Kamahi dan produk fermentasi ikan (Yoon et al., 2002).

Analog dengan fermentasi kedelai, Tempe merupakan makanan fermentasi berbahan baku kedelai dari Indonesia difermentasi oleh jamur berfilamen seperti Rhizopus sp., Sumi et al. juga melaporkan bahwa ekstrak air dari tempe 
menunjukkan adanya aktivitas trombolitik (Sugimoto et al., 2007).

Produksi enzim fibrinolitik dipengaruhi oleh beberapa faktor, antara lain volume inokulum, kondisi fermentasi (suhu dan waktu inkubasi) (Sher et al., 2011). Optimasi dan kontrol kondisi fermentasi merupakan salah satu tahap penting dalam memproduksi metabolit (Han and Nout, 2001). Sher et al., 2011 menyatakan bahwa waktu inkubasi mempengaruhi pertumbuhan miselia jamur Rhizopus oligosporus, optimasi dilakukan untuk mendapatkan waktu maksimum pertumbuhan jamur dan juga mencegah tahap sporulasi pada tempe gandum.

Enzim fibrinolitik yang dihasilkan oleh jamur dapat diketahui melalui uji aktivitas menggunakan media fibrin plate. Adanya enzim fibrinolitik maka akan menghidrolisis sehingga media yang awalnya berwarna putih keruh akan berubah menjadi jernih (Suri et al., 2013). Uji aktivitas fibrinolitik juga dilakukan dengan menggunakan spektrofotometer seperti metode Liu et al., 2006.

Mengacu dari latar belakang permasalahan tersebut, pada penelitian ini akan dilakukan fermentasi padat pada kacang kedelai (Glycine max) oleh Rhizopus oryzae FNCC 6078 dan dengan memperhatikan faktor-faktor di atas maka dilakukan optimasi produksi enzim fibrinolitik. Tujuannya adalah untuk mengetahui bahwa melalui fermentasi padat dengan kedelai, Rhizopus oryzae FNCC 6078 dapat menghasilkan enzim fibrinolitik dan mendapatkan kondisi fermentasi yang optimum dalam memproduksi enzim fibrinolitik.

\section{Bahan dan Cara kerja}

Bahan. Kacang kedelai (Glycine max (L) Merr.) varietas Wilis yang didapatkan dari Balai Penelitian Kacang - Kacangan dan Umbi - Umbian Malang. Rhizopus oryzae FNCC 6078 yang didapatkan dari Laboratorium Mikrobiologi Pusat Antar Universitas Pangan Gizi Universitas Gajah Mada. Fibrin Bovine Blood dari SIMAGCHEN, kaplet salut NATTO-10 NSK II 100 mg Co Q-10 30 mg, akuades, dapar Tris - $\mathrm{HCl}$ (Molecular Biology Grade) 0,05 M pH 5,00; $\mathrm{NaCl}$ 0,9\%, TCA (Tri Chloro Acetic) for analysis dari Merck, HCl 0,1 M, KH2PO4 0,1 M, Na2B4O7 0,05 M, Metilen blue 1000 ppm, tirosin 100 ppm, alkohol 70\%, Potato Dextrose Agar (PDA) CM0139, agarosa.

Alat. autoclave HL - 340 Series Vertical Type Steam sterilisizer, incubator Memmert, spektrofotometer Genesys-20, timbangan digital Sartorius Type BP 221S, laminar air flow cabinet, magnetic stirrer, lemari pendingin, ultra sentrifuge, sentrifuge Hettich Zentrifugen EBA 20, vortex Thermolyne Maxi Mix, spektrofotometer hp. 8452 a, pH meter Fisher Versamix, jangka sorong.

\section{Kultur Rhizopus oryzae FNCC 6078}

Kultur dilakukan di dalam Laminar Air Flow dengan teknis aseptis. Menginokulasikan satu ose isolat murni Rhizopus oryzae FNCC 6078 pada media PDA. Inokulum disimpan dalam inkubator pada suhu 37oC selama 3 hari, lalu disimpan dalam lemari pendingin bersuhu $4 \mathrm{oC}$.

\section{Penyiapan suspensi inokulum dan pembuatan tempe secara aseptis}

Pembuatan suspensi spora jamur Rhizopus oryzae adalah dengan cara menambahkan $10 \mathrm{~mL} \mathrm{NaCl} \mathrm{0,9 \%}$ steril ke dalam tabung inokulum yang telah diinkubasi selama 3 hari, kemudian divortex sampai spora jamur terlepas dari medianya ( \pm 15 menit), supernatan dipindahkan dalam Erlenmeyer steril. Suspensi spora diukur persen transmitan dengan menggunakan spektrofotomoter pada panjang gelombang $580 \mathrm{~nm}$. Penambahan $\mathrm{NaCl} 0,9 \%$ dilakukan hingga didapat transmitan $25 \%$.

Kacang kedelai 200 gram di sortir terlebih dahulu, dicuci dengan akuades, kemudian direbus hingga mendidih (15 menit) untuk memudahkan pengelupasan kulit. Dilakukan pengelupasan kulit kacang. Setelah itu direndam semalam dengan akuades $600 \mathrm{~mL}$ selama 16 jam untuk membuat suasana asam. Setelah dicuci kacang kedelai direbus kembali dengan air $600 \mathrm{~mL}$ selama 10 menit. Selanjutnya dikeringkan dan didinginkan pada suhu kamar. Kacang kedelai kering ditimbang sebanyak 50 gram per satu cawan petri, kemudian ditambahkan suspensi dari inokulasi jamur tempe (Rhizopus oryzae) $25 \% \mathrm{~T}$ sebanyak $1,0 \mathrm{~mL}$ dengan cara disemprotkan ke dalam cawan petri. Goyanggoyangkan hingga suspensi spora dan kacang kedelai tercampur homogen. Inkubasi dalam inkubator bersuhu 300C selama 42 jam.

\section{Optimasi produksi enzim fibrinolitik}

\section{Optimasi volume inokulum}

Optimasi volume inokulum dilakukan dengan mengubah volume inokulum $25 \% \mathrm{~T}$ yaitu $0,5 \mathrm{~mL} ; 1,0$ $\mathrm{mL} ; 1,5 \mathrm{~mL}$ dan 2,0 mL. Waktu inkubasi 42 jam dan suhu inkubasi $30 \mathrm{oC}$.

\section{Optimasi suhu inkubasi}

Optimasi suhu inkubasi dilakukan dengan mengubah suhu yaitu, 30, 35, 40, 45oC. Volume inokulum $25 \% \mathrm{~T} 1,0 \mathrm{~mL}$ dan waktu inkubasi 42 jam.

Optimasi waktu inkubasi

Optimasi waktu inkubasi dilakukan pada beberapa waktu yaitu 30, 36, 42, dan 48 jam. Volume inokulum $25 \% \mathrm{~T} 1,0 \mathrm{~mL}$ dan suhu inkubasi $30 \mathrm{oC}$. 


\section{Isolasi enzim kasar (crude enzyme)}

$50 \mathrm{~g}$ tempe ditimbang dengan menggunakan timbangan analitik dan diekstraksi dengan dapar tris $\mathrm{HCl} 0,05 \mathrm{M}$ pH 5,0 menggunakan blender. Untuk berat tempe sebesar 50,0 g membutuhkan larutan dapar sebanyak $125 \mathrm{~mL}$ dapar tris $\mathrm{HCl} \mathrm{pH} \mathrm{5,00.}$ Dilakukan dengan penambahan volume dapar sedikit demi sedikit agar dicapai hasil yang optimal (ekstraksi 3x 10 detik). Setelah itu, masukkan ekstrak ke dalam tabung sentrifugasi plastik. Lakukan sentrifuge $9000 \mathrm{rpm}$ selama 10 menit dengan suhu 40C. Supernatan dipisahkan dan disimpan pada suhu $-20 \mathrm{oC}$.

\section{Uji aktivitas fibrinolitik dengan fibrin plate}

Media fibrin plate dibuat dengan menambahkan fibrin $0,3 \%$ dan agarosa $1,7 \%$ dalam dapar asam borat (pH 7,8). Sebanyak $20 \mathrm{~mL}$ dari campuran tersebut dituangkan dalam petri yang sudah ditambahkan metilen blue $400 \mu \mathrm{L}$ sebagai pewarna untuk memperjelas zona jernihyang terbentuk sebanyak. Fibrin plate didiamkan pada suhu kamar selama 30 menit agar memadat dan membentuk lapisan fibrin. Pada media dibuat 7 lubang dengan menggunakan pelubang steril berdiameter $7 \mathrm{~mm}$. Sebanyak $100 \mu \mathrm{L}$ sampel ditempatkan pada masing-masing lubang. Fibrin plate diinkubasi pada suhu 37 oC selama 18 jam. Akan terbentuk zona jernih, lalu diamati dan diukur dengan menggunakan jangka sorong.

\section{Uji aktivitas fibrinolitik dengan spektrofotometer.}

Aktivitas fibrinolitik diukur dengan menggunakan spektrofotometer. Dibuat dua tabung dalam uji ini, yaitu sampel dan blanko. Tabung blanko berisi 1000 $\mu \mathrm{L}$ dapar Tris $\mathrm{HCl} \mathrm{pH} 5,00$ dan $500 \mu \mathrm{L}$ larutan fibrin $3 \%$ (pH 7,80), tabung sampel berisi $950 \mu \mathrm{L}$ dapar Tris $\mathrm{HCl}$ pH 5,00; $50 \mu \mathrm{L}$ crude enzyme dan $500 \mu \mathrm{L}$ larutan fibrin $3 \%(\mathrm{pH} \mathrm{7,80)}$ kemudian kedua tabung diinkubasi selama 10 menit pada suhu $37^{\circ} \mathrm{C}$. Reaksi dalam tabung dihentikan dengan penambahan TCA $5 \%$ sebanyak 1,0 mL, kemudian disentrifugasi dengan kecepatan $2500 \mathrm{rpm}$ selama 10 menit. Supernatan yang didapat diukur absorbansinya pada panjang gelombang $274 \mathrm{~nm}$. Satu unit aktivitas fibrinolitik adalah jumlah enzim yang dapat melepas $1 \mu \mathrm{mol}$ tirosin per menit dalam tiap $\mathrm{ml}(\mathrm{Unit} / \mathrm{mL}) \mathrm{di}$ bawah kondisi uji.

Aktivitas fibrinolitik dihitung dengan menggunakan rumus :

$\mathrm{Ae}=(\mathrm{x} . \mathrm{V}) /(\mathrm{a} . \mathrm{b}) \times 1 / \mathrm{BM}$

Keterangan :

$$
\begin{array}{ll}
\text { Ae } & =\text { Aktivitas enzim }(\text { Unit } / \mathrm{mL}) \\
\mathrm{x} & =\text { Kadar tirosin }(\mu \mathrm{g} / \mathrm{mL})
\end{array}
$$

$$
\begin{array}{ll}
\mathrm{V} & =\text { Volume total sampel tiap tabung }(\mathrm{mL}) \\
\mathrm{a} & =\text { Volume crude enzyme }(\mathrm{mL}) \\
\mathrm{b} & =\text { Waktu reaksi (menit) } \\
\mathrm{BM} & =\text { Berat Molekul tirosin }(181,19) \text { Linieritas }
\end{array}
$$
Untuk menentukan linieritas, dibuat kurva hubungan antara konsentrasi dan area EGCG pada berbagai macam konsentrasi. Ditimbang teliti 5,000 mg dengan neraca mikro analitik kemudian dibuat 5 macam konsentrasi 50-150\% dari kadar analit yang diperkirakan (Indrayanto \& Yuwono, 2002). Konsentrasi yang akan dibuat yaitu 50 ppm, 100 ppm, 150 ppm, 200 ppm dan 250 ppm. Konsentrasi tersebut dibuat dengan cara melarutkan 5,000 mg EGCG standar dengan metanol sampai volume ad 10,0 ml dalam labu ukur sehingga didapatkan larutan baku induk $500 \mathrm{ppm}$. Dari larutan induk $500 \mathrm{ppm}$ dipipet $0,5 \mathrm{ml} ; 1,0 \mathrm{ml} ; 2,0 \mathrm{ml}$ masing-masing diencerkan dengan metanol sampai volume ad 5,0 $\mathrm{ml}$ sehingga didapatkan konsentrasi 50 ppm; 100 ppm dan 200 ppm. Untuk konsentrasi $250 \mathrm{ppm}$ dibuat dengan memipet 5,0 $\mathrm{ml}$ baku induk, diencerkan dengan metanol sampai volume ad 10,0 ml. Dari konsentrasi 250 ppm dipipet 3,0 ml, kemudian diencerkan dengan metanol sampai volume ad 5,0 $\mathrm{ml}$ sehingga didapat konsentrasi $150 \mathrm{ppm}$.

\section{Hasil Dan Pembahasan}

Zona jernih hasil uji aktivitas fibrinolitik menggunakan fibrin plate ditunjukkan pada gambar 1.

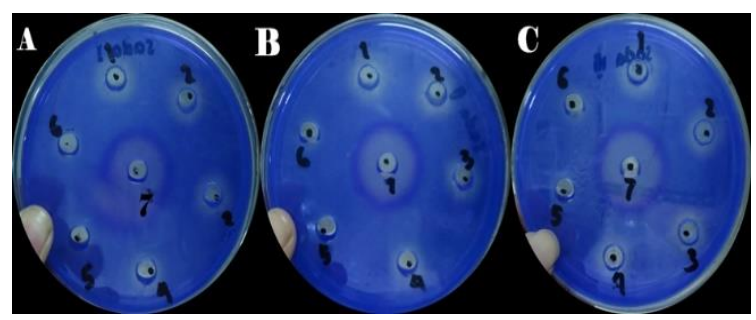

Gambar 1. Hasil uji aktivitas fibrinolitik dengan fibrin plate (A) replikasi 1, (B) replikasi 2, (C) replikasi 3. Terbentuk zona jernih pada sampel, (1) crude enzyme 1; (2) crude enzyme 2; (3) crude enzyme 3; (4) kontrol negatif; (5) dapar tris $\mathrm{HCl} \mathrm{0,05}$ $\mathrm{M} \mathrm{pH} \mathrm{5,00;} \mathrm{(6)} \mathrm{suspensi} \mathrm{jamur} \mathrm{R.} \mathrm{oryzae;} \mathrm{(7)} \mathrm{kontrol}$ positif (nattokinase)

Hasil pengkuruan diameter zona jernih sampel crude enzyme, kontrol negatif dan positif, suspensi jamur R.oryzae dan dapar tris $\mathrm{HCl} \mathrm{pH}$ 5,00 ditabelkan pada tabel 1 . 
Berkala Ilmiah Kimia Farmasi, Vol.8 No.1 Juni 2021 Hal 1 - 6

P-ISSN: 2302-8270

E-ISSN: 2808-1048

Tabel 1. Diameter zona jernih enzim fibrinolitik tempe

\begin{tabular}{|c|c|c|c|c|c|}
\hline \multicolumn{6}{|c|}{ Diameter Zona Jernih (mm) } \\
\hline \multirow{2}{*}{$\begin{array}{l}\text { Suspensi } \\
\text { R. oryzae }\end{array}$} & \multicolumn{3}{|c|}{ Replikasi Tempe } & \multirow{2}{*}{$\mathbf{K}(+)$} & \multirow{2}{*}{$\mathbf{K}(-)$} \\
\hline & 1 & 2 & 3 & & \\
\hline 8,00 & 13,11 & 13,38 & 13,15 & 28,20 & 9,00 \\
\hline 7,32 & 13,25 & 12,25 & 13,00 & 28,40 & 8,00 \\
\hline 7,30 & 13,12 & 13,25 & 13,08 & 28,40 & 8,40 \\
\hline $\begin{array}{l}7,54 \pm \\
0,40\end{array}$ & $\begin{array}{l}13,16 \\
\pm 0.08\end{array}$ & $\begin{array}{l}12,96 \\
\pm 0.62\end{array}$ & $\begin{array}{l}13,08 \\
\pm 0.08\end{array}$ & $\begin{array}{l}23,33 \\
\pm 0.12\end{array}$ & $\begin{array}{l}8,47 \\
\pm 0,50\end{array}$ \\
\hline
\end{tabular}

Keterangan :

$\mathrm{K}(+)=$ Kontrol positif nattokinase, $\mathrm{K}(-)=$ Kontrol negatif ekstrak kedelai tanpa penambahan jamur (-) : Tidak menghasilkan zona jernih

Zona jernih pada uji fibrinolitik dengan sampel crude enzyme ataupun pada nattokinase merupakan hasil pemecahan fibrin menjadi asam amino yang larut. Pembuatan tempe dilakukan replikasi tiga kali, masing-masing dianalisis aktivitas fibrinolitiknya dengan mengamati zona jernih sampel crude enzyme. Hasilnya didapatkan berdiameter $13,16 \pm 0,08 ; 12,96$ $\pm 0,62 ; 13,08 \pm 0,08 \mathrm{~mm}$. Suspensi jamur Rhizopus oryzae $25 \% \mathrm{~T}$ juga memberikan zona jernih berdiameter 7,54 $\pm 0,40 \mathrm{~mm}$. Dalam hal ini suspensi R. oryzae saja dapat menghasilkan zona jernih, karena jamur mampu memproduksi protease walaupun produksinya relatif sedikit dibandingkan produksi enzim protease hasil fermentasi tempe (Rauf et al., 2010). Ekstrak kacang kedelai sebagai kontrol negatif juga menghasilkan zona jernih pada uji dengan fibrin plate. Zona jernih yang didapatkan berdiameter 8,47 $\pm 0,50 \mathrm{~mm}$. Mekanisme mengapa kacang kedelai dapat memecah fibrin belum diketahui secara jelas, akan tetapi kandungan isoflavon dalam kacang kedelai telah diteliti mampu menghambat oksidasi LDL dan meningkatkan HDL sehingga dapat mencegah aterosklerosis yang merupakan penyebab trombus (Yang et al., 2011). Dapar tris $\mathrm{HCl}$ yang digunakan sebagai pembanding atau konrol pelarut yang diuji dengan fibrin plate tidak terbentuk zona jernih, berarti bahwa tidak memberikan pengaruh pada hidrolisis fibrin. Terbentuknya zona jernih dari proses hidrolisis fibrin pada uji fibrin plate.

Hasil optimasi kondisi fermentasi untuk memproduksi enzim fibrinolitik dengan perbedaan volume inokulum seperti ditunjukkan pada gambar 2 .

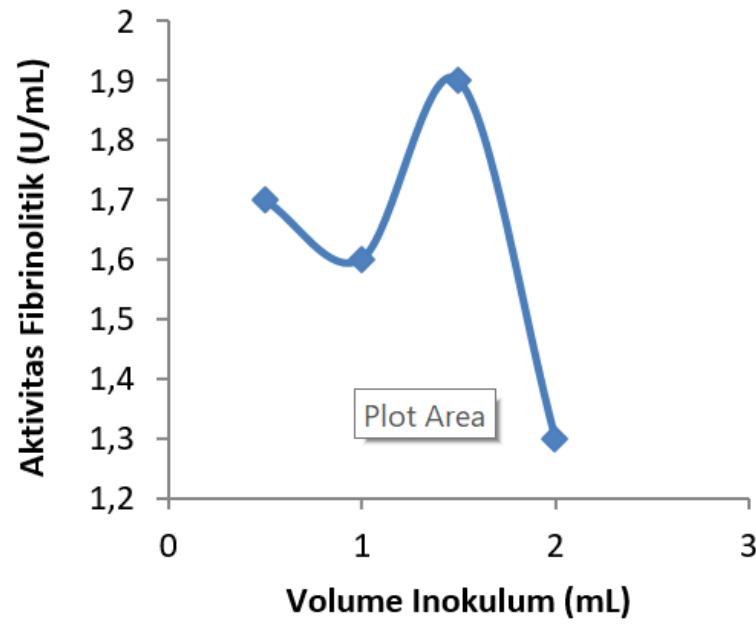

Gambar 2. Pengaruh volume inokulum terhadap produksi enzim fibrinolitik (U/ml)

Optimasi produksi enzim fibrinolitik dilakukan dengan volume inokulum (suspensi jamur 25\% T) yaitu $0,5 \mathrm{~mL} ; 1,0 \mathrm{~mL} ; 1,5 \mathrm{~mL} ; 2,0 \mathrm{~mL}$, dan diinkubasi pada suhu $30 \mathrm{oC}$ selama 42 jam. Diperoleh aktivitas fibrinolitik berturut-turut $1,7 \pm 0,1 ; 1,6 \pm 0,5 ; 1,9 \pm$ 0,$2 ; 1,3 \pm 0,1 \mathrm{U} / \mathrm{ml}$. Aktivitas maksimum dicapai saat volume inokulum $1,5 \mathrm{~mL}$ dengan aktivitas $1,9 \mathrm{U} / \mathrm{mL}$. Pengaruh volume inokulum dalam fermentasi untuk memproduksi enzim fibrinolitik, apabila volume inokulum yang ditambahkan semakin meningkat maka terjadi pertumbuhan spora yang terlalu padat sehingga menyebabkan penurunan aktivitas enzim karena penurunan nutrisi (Rauf et al., 2010). Pada sisi lain, volume inokulum yang rendah maka biomassa tidak akan mencukupi dalam memberikan aktivitas enzim (Sher et al., 2011).

Pengaruh waktu inkubasi terhadap produksi enzim fibrinolitik ditunjukkan pada gambar 3 .

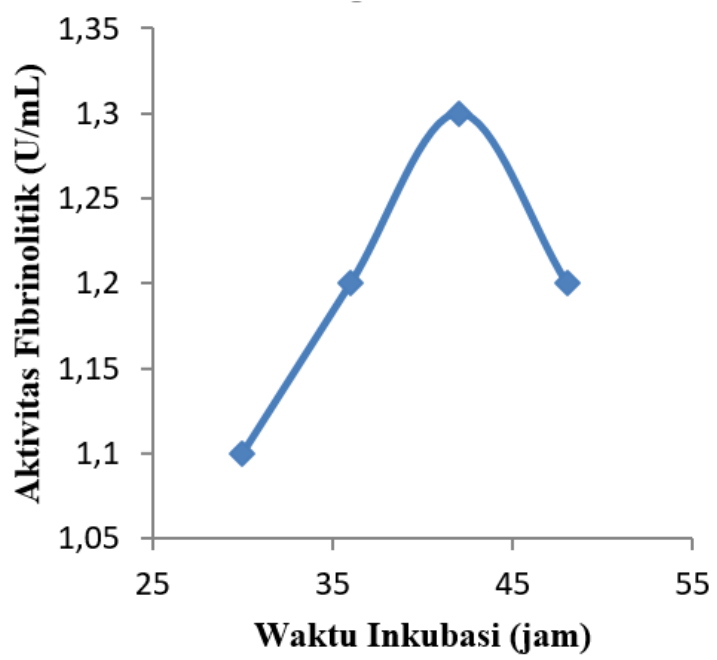


Gambar 3. Pengaruh waktu inkubasi terhadap produksi enzim fibrinolitik

Variasi waktu inkubasi dilakukan dengan rentang 6 jam, yaitu 30, 36, 42 dan 48 jam, dengan volume inokulum (suspensi jamur $25 \% \mathrm{~T}$ ) yang digunakan $1,0 \mathrm{~mL}$ dan suhu inkubasi $30 \mathrm{oC}$. Diperoleh aktivitas fibrinolitik untuk masing - masing waktu inkubasi adalah $1,1 \pm 0,1 ; 1,2 \pm 0,4 ; 1,3 \pm 0,2$; dan 1,2 $\pm 0,1 \mathrm{U} / \mathrm{mL}$. Aktivitas maksimum dicapai pada waktu inkubasi 42 jam yaitu $1,3 \mathrm{U} / \mathrm{mL}$. Waktu inkubasi penting untuk pertumbuhan miselia yang maksimum dan untuk menghindari terjadinya sporulasi pada tempe (Sher et al., 2011). Rauf et al., 2010 menyatakan bahwa semakin meningkat waktu inkubasi menyebabkan terjadinya penurunan unit enzim karena terjadinya inaktivasi oleh protease lain. Pada waktu inkubasi 30 hingga 42 jam terjadi peningkatan aktivitas enzim, hal tersebut menunjukkan jamur ada pada fase logaritmik (pertumbuhan). Pada fase logaritmik jamur membutuhkan energi untuk tumbuh sehingga diperlukan enzim untuk memecah substrat protein di media sebagai sumber nutrisi karena tidak semuanya dapat digunakan secara langsung oleh jamur. Pada waktu inkubasi 48 jam terjadi penurunan aktivitas fibrinolitik, menunjukkan jamur ada pada fase stasioner hingga fase kematian. pada fase tersebut terjadi penurunan nutrisi sehingga produksi enzim oleh jamur juga menurun. Jumlah jamur yang mati meningkat pada fase stasioner hingga fase kematian juga mempengaruhi jumlah biomassa yang menghasilkan enzim. Pada fase kematian terjadi pemecahan protease oleh protease lain (autolisis) karena adanya usaha mempertahankan diri oleh jamur yang masih hidup sehingga memecah protease lain untuk dijadikan sebagai sumber nutrisi.

Pengaruh suhu inkubasi terhadap fermentasi untuk produksi enzim fibrinolitik ditunjukkan pada gambar 4.

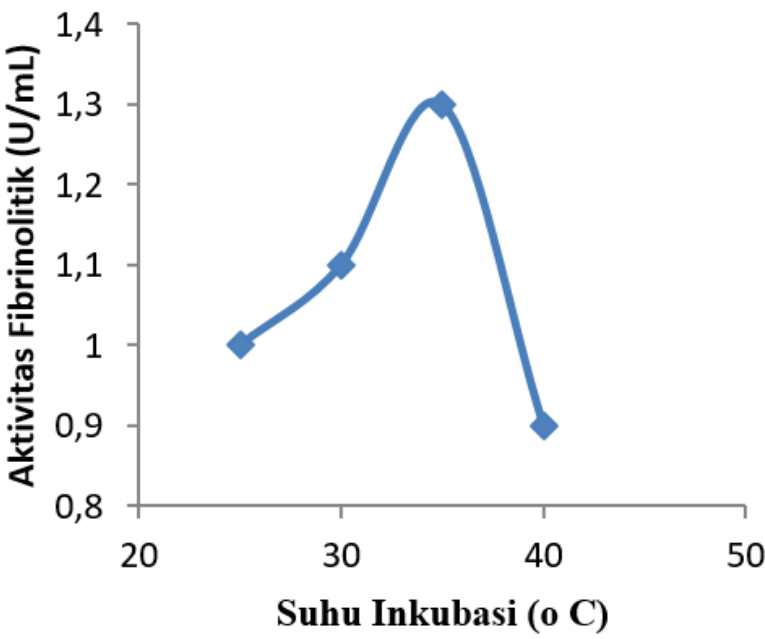

Gambar 4. Pengaruh Suhu Inkubasi terhadap produksi enzim fibrinolitik

Optimasi produksi dilakukan pada suhu 25, 30, 35 dan $40 \mathrm{oC}$ dengan volume inokulum $1,0 \mathrm{~mL}$ dan waktu inkubasi 42 jam. Diperoleh aktivitas fibrinolitik berturut-turut adalah $1,0 \pm 0,1 ; 1,1 \pm 0,2$; $1,3 \pm 0,1$ dan $0,9 \pm 0,1 \mathrm{U} / \mathrm{mL}$. Aktivitas maksimum dicapai pada suhu $350 \mathrm{C}$ yaitu $1,3 \mathrm{U} / \mathrm{mL}$. Pengaruh suhu terhadap produksi enzim adalah pada pertumbuhan miselia jamur. Suhu yang lebih tinggi dari suhu optimum memberikan pengaruh pada aktivitas metabolisme jamur yang akan menghambat pertumbuhan miselia (Rauf et al.,2010; Sher et al., 2011). Jamur Rhizopus sp. merupakan mikroorganisme mesofilik yang memiliki pertumbuhan optimum pada suhu 25-37oC. Di bawah suhu optimum jamur akan memiliki pertumbuhan yang lambat sehingga produksi enzim juga turun. Suhu diatas suhu optimum selain memberikan pertumbuhan jamur yang lambat juga dapat menyebabkan denaturasi enzim yang dihasilkan.

Hasil optimasi kondisi fermentasi untuk produksi protease dengan menggunakan Rhizopus oryzae (RO IIT RB-13, NRRL-21498) pada kulit gandum didapatkan jumlah spora optimum adalah 2 × 105/g kulit gandum dan suhu optimum inkubasi adalah $32^{\circ} \mathrm{C}$ (Tunga et al., 1998).

\section{Kesimpulan}

Tempe hasil fermentasi Rhizopus oryzae FNCC 6078 mengandung enzim fibrinolitik.

Volume inokulum optimum dalam memproduksi enzim fibrinolitik adalah 1,5 mL suspensi jamur Rhizopus oryzae FNCC 6078 (25\% T) dalam 50,0 g kacang kedelai.

Suhu inkubasi optimum dalam produksi enzim fibrinolitik adalah $35 \mathrm{oC}$

Waktu inkubasi optimum dalam produksi enzim fibrimolitik adalah 42 jam

\section{Daftar Pustaka}

Arunachalam, C., and Aiswarya, M.,2011. Microbial fibrinolytic enzyme - a deity for thrombolysis. Advanced Biotech, Vol. 10, Issue. 9, pp. 8 11.

Bakta, I.M., 2007. Thrombosis dan usia lanjut. J. Peny. Dalam, Vol. 8, No.2, hal. 148-160.

Han, B.Z., and Nout, M.J.R., 2001, Effect of temperature, watter activity, and gas atmosphere on mycelia growth of tempe fungi Rhizopus microsporus var. microsporus and R. microsporus var. oligosporus. World Journal of Microbiology and Biotechnology, 16 , pp. 853- 858 . 
Kotb, E., 2012. Fibrinolytic Bacterial Enzymes with Thrombolytic Activity. Heidelberg: Springer.

Liu, J.G., Xing, J.M., Chang, T.S., Liu, H.Z., 2006. Purification of nattokinase by reverse micelles extraction from fermentation broth: effect of temperature and phase volume ratio. Bioprocess Biosyst Eng, pp. 267-273

Rauf, A., Irfan, M., Nadeem, M., Ahmed, I., Iqbal, H.M.N., 2010. Optimization of growth conditions from Rhizopus oligosporus through solid state fermentation of sunflower meal. International Journal of Agricultural and Biological Sciences, 1:1, pp. 40-43

Sher, M.G., Nadeem, M., Syed, Q., Abass, S., and Hassan, A., 2011. Study on protease from barley tempeh and in vitro protein digestibility. Jordan Journal of Biological Sciences, vol. 4, no. 4, pp. 257-264.

Sugimoto, S., Fuji, T., Morimiya, T., Johdo, O., and Nakamura, T., 2007. The Fibrinolytic Activity of a Novel Protease Derived from a Tempeh Producing Fungus Fusarium sp. BLB. Biosci, Botechnol, Biochem, 71, 70153-1-6.
Suri, W.L., Syukur, S., and Jamsari, 2013. Optimization of protease activity from Lactic Acid Bacteria (LAB) Pediococcus pentosaceus isolated from soursop fermentation (Annona muricata L.). Jurnal Kimia Unand, vol.2, no.1, pp. 18-25.

Tunga, R., Banerjee, R., Bhattacharyya, B.C., 1998. Optimizing some factors affecting protease production under solid state fermentation. Bioprocess Enginering, 19, pp. 187-190.

Yang, H. J., Park, S., Pak, V., Chung, K. R., Kwon, D. Y., 2011. Fermented soybean products and their bioactive compounds. In: H. El-Shemy. Soybean and Health, Egypt: InTech, pp. 2253.

Yoon, Seon-Joo, Yu, M., Sim, G., Kwon, S., Hwang, J., Shin, J., Yeo, I., and Pyun, Y., 2002. Screening and characterization of microorganism with fibrinolytic activity from fermented foods. J. Microbiol Biotechnol, 12(4), pp. 649-656. 